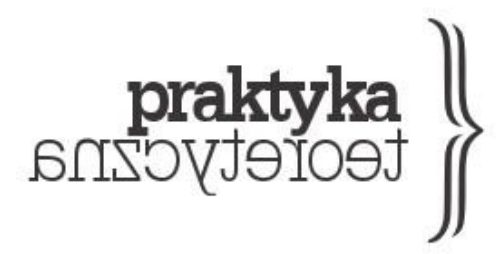

\title{
WYJAŚNIAMY CZY UTRZYMUJEMY STATUS QUO? TEORIE O „GLĘBOKO ZAKORZENIONYCH” RÓŻNICACH PLCIOWYCH JAKO SAMOSPEŁNIAJĄCA SIĘ PRZEPOWIEDNIA ${ }^{1}$
}

\author{
CORDELIA FINE
}

\section{PRZEŁOŻYŁA: ALEKSANDRA DERRA}

\begin{abstract}
Abstrakt: W poniższym artykule przedstawiam dane na poparcie twierdzenia o wpływie naukowych opisów grup społecznych na same te grupy oraz na badane zjawiska mentalne. Zarówno w nauce, jak i w popularnym przekazie medialnym powszechna jest kontrowersyjna hipoteza o istnieniu głęboko zakorzenionych różnic między mózgami mężczyzn i kobiet, które przyczyniaja się do powstawania różnic w zachowaniach typowych dla danej płci. Przedstawiam dowody na to, że takie stwierdzenia, niezależnie od ich zasadności naukowej, moga podtrzymywać istnienie różnic płciowych, które maja wyjaśniać. Przekonuję, że choć potrzeba dalszych badań, powyższe twierdzenia mogą stać się samospełniającą się przepowiednia, oddziałując na odbiór społeczny, zachowania oraz nastawienie. Rzeczywisty wpływ efektów badań naukowych na nasze umysły i społeczeństwo oraz to, że wszystkie hipotezy naukowe podlegają dyskusji i podważaniu, wskazuje na potrzebę rozważenia przez naukowców etycznych implikacji ich pracy.
\end{abstract}

Słowa kluczowe: esencjalizm, neuroetyka, płeć społeczno-kulturowa (gender), stereotypy.

1 Źródło: Fine, Cordelia. 2012. „Explaining, or Sustaining, the Status Quo? The Potentially Self-Fulfilling Effects of »Hardwired« Accounts of Sex Differences”, Neuroethics 5: 285-294. Opublikowano za zgoda wydawcy [przyp. tłum.]. 


\section{„Teoria na temat gwiazd nigdy nie stanie się częścią istnienia samych gwiazd. \\ Teoria na temat człowieka wkracza w jego świadomość, dookreśla jego samorozumienie i przekształca jego egzystencję.”}

Herschel 1965, 8

\section{Wprowadzenie}

Czy istnieja głęboko zakorzenione różnice między mózgami kobiet i mężczyzn, które przynajmniej częściowo wyjaśniałyby płciowe różnice zachowań, a docelowo - także różnice ról społecznych i statusu?

Zgodnie z wpływową hipotezą o „organizacji mózgu” dotyczącą zróżnicowania płciowego, testosteron płodowy, którego średni poziom różni się znacznie u chłopców i dziewczynek pomiędzy ósmym a dwudziestym czwartym tygodniem ciąży, wywiera stały wpływ na mózg, a tym samym kształtuje typowe dla płci zachowania, łącznie z zainteresowaniami i zdolnościami (najnowsze podsumowanie tego stanowiska można znaleźć w: Hines 2010). Na przykład Simon Baron-Cohen i jego współpracownicy (2003, 2005) ogłosili, że testosteron płodowy oddziałuje na rozwój mózgu w taki sposób, że jego niższy poziom skutkuje „kobiecym mózgiem”, który jest „w przeważającej mierze zaprogramowany na empatię”, a poziom wyższy - „mózgiem męskim”, „w przeważającej mierze zaprogramowanym na rozumienie i tworzenie systemów" (Baron-Cohen 2003, 1, usunięto podkreślenie z cytowanego tekstu).

Badania $z$ zastosowaniem funkcjonalnego oraz strukturalnego neuroobrazowania często prowadzą do postawienia tezy, że mózgi mężczyzn i kobiet znacznie się od siebie różnią (Kaiser et al. 2009, tabela 1). Choć wiele odkryć takich różnic jest jednorazowa i przeważnie post hoc, to często wnioskuje się, że męski i kobiecy mózg różnią się od siebie sposobem połączenia półkul: typowy mózg męski uważa się za funkcjonalnie bardziej intrapółkulowy, a kobiety - za bardziej interpółkulowy. Badacze przypuszczają, że powyższe różnice mają konsekwencje funkcjonalne w przypadku typowych dla płci zdolności, takich jak rozumienie myśli i uczuć innych (zdolność do empatii), rozumienie systemów: fizycznych, technicznych i innych (posługiwanie się systemami), rozumienie matematyki i nauki (BaronCohen 2005; Gur, Gur 2007; Halpern et al. 2007).

Hipoteza Barona-Cohena na temat empatii i posługiwania się systemami oraz ogólniejsze ujęcie zróżnicowania płciowego oparte na „organizacji mózgu”, od którego powyższa hipoteza się wywodzi, zostały poddane krytyce w innym miejscu (Fine 2010a; Grossi 2008; Grossi, Fine 2012; Jordan-Young 2010). Autorzy wskazali na istotne problemy empiryczne, metodologiczne i pojęciowe. Obejmowały one wiarygodność i pochodzenie różnic płciowych w zachowaniu, sugerowany związek między poziomem testosteronu 
płodowego a późniejszym zachowaniem typowym dla danej płci, istnienie dymorfizmu płciowego w mózgu i jego powiązanie z zachowaniem lub stylem poznawczym oraz nazbyt uproszczona koncepcje rozwoju w zaproponowanej teorii. W innych pracach omówiłam również kilka ważnych problemów związanych z wytwarzaniem i interpretacją „faktów” na temat różnic płciowych mózgu (Fine 2010b, 2010c).

Nie chcę tu powtarzać tej krytyki; zamierzam wykazać, że przedstawianie takiego rozumienia różnic płciowych w poznaniu i zachowaniu z dużym prawdopodobieństwem funkcjonuje jako samospełniająca się przepowiednia. Barry Schwartz posłużył się pojęciem „technologii idei”, by wyrazić pogląd, że tak jak konkretne przedmioty wytwarzane przez naukę i technologie potrafia wpływać na nasze życie, tak czynią to i tworzone przez naukę idee i pojęcia (Schwartz 1997). Zwraca jednak uwagę, że o ile wytwory materialne technologii co do zasady oddziałuja na społeczeństwo tylko wtedy, gdy znajduja solidne poparcie w nauce, o tyle idee naukowe moga wpływać na życie jednostek i społeczeństwo nawet wtedy, kiedy są fałszywe. Badania naukowe poszczególnych grup społecznych są oczywistym przykładem tego zjawiska. Ian. Hacking opisał efekt „pętli” lub „sprzężenia zwrotnego w poznaniu i kulturze", z którym mamy do czynienia, gdy myślenie przyczynowe danej grupy społecznej zmienia sam charakter tej grupy, prowadząc do dalszych zmian w myśleniu przyczynowym (1995). Podobnie Suparna Choudhury i jej współpracownicy, odwołujący się zwłaszcza do społecznego wpływu neuronauk, przekonywali, że obraz „faktów o mózgu” w mediach, strategiach politycznych i odbiorze laików kształtuje społeczeństwo w sposób, który może wpływać na samo badane zjawisko mentalne (Choudhury, Nagel, Slaby 2009).

W artykule tym chciałabym przybliżyć dane, które pokazuja takie oddziaływanie twierdzeń o głęboko zakorzenionych różnicach płciowych. Skupiam się głównie na tych, zgodnie z którymi mózg kobiecy jest zaprogramowany na empatię, natomiast mózg męski na systemy. W pierwszej kolejności analizuje dowody na to, że stereotypy płciowe wpływaja na percepcję i zachowanie. Następnie badam, na ile teorie o głęboko zakorzenionych różnicach płciowych zwiększaja ten wpływ. Wreszcie zastanawiam się, jakie obszary wymagaja dalszych badań, jednocześnie zaznaczając, że dostępne już dane skłaniaja do postawienia pytań natury etycznej.

\section{Stereotypy i umysły}

W psychologii kulturowej i społecznej przyjmuje się, że psyche „nie jest osobnym bytem upakowanym w mózgu. Jest raczej pewną struktura składająca się z procesów psychologicznych, ukształtowanych przez swoje otoczenie kulturowe, a tym samym ściśle do otoczenia dopasowanych" (Kitayama, Cohen 2007, xiii). W przypadku społecznej kategorii płci struktura procesów psychologicznych zaczyna kształtować się we wczesnym 
dzieciństwie, kiedy dzieci zaczynają nabywać „korelaty kulturowe” płci (Bem 1983). Zanim zaczną chodzić do szkoły, nabywają dużą wiedzę o stereotypach płciowych, to jest wiedzę o cechach, działaniach i zawodach typowo przypisywanych obu płciom (Miller, Trautner, Ruble 2006). Baron-Cohen, opisując „kobiecy mózg” jako zaprogramowany na empatię, odzwierciedla stereotypy płciowe na temat kobiet jako zorientowanych na wspólnotę (to jest troszczących się zarówno o innych, jak i o siebie) i skoncentrowanych na ludziach, oraz na temat mężczyzn jako zorientowanych na działanie [agentic] (to jest asertywnych, ambitnych indywidualistach), skupionych na przedmiotach (Prentice, Carranza 2002). Hipoteza, że „męski mózg” jest ściśle zaprogramowany na systemy, jest zgodna ze stereotypem mężczyzn jako bardziej logicznych i analitycznych niż kobiety oraz lepiej sprawdzających się w zawodach naukowych i technicznych (Nosek et al. 2009). Poza kulturowo podzielanymi przekonaniami na temat płci o charakterze opisowym, badania naukowe dookreślają również kulturowo podzielane nakazy oraz zakazy - normatywne przekonania o tym, jak powinni zachowywać się mężczyźni i kobiety. Na przykład zachowanie wspólnotowe jest szczególnie silnie przypisywane kobietom, podczas gdy zachowania związane z działaniem sa częściej przypisywane mężczyznom (Prentice, Carranza 2002).

Nawet jeśli jednostki nie opowiadają się otwarcie za stereotypami płciowymi, to ich treść może jednak wpływać na ich percepcję, osądy i zachowanie, kiedy zostanie uaktywniona przez istotne ze względu na płeć wskazówki z najbliższego otoczenia społecznego. Kluczową dla zrozumienia ich możliwego wpływu na postrzeganie społeczne i zachowanie jest koncepcja, którą Bargh i Williams opisują następująco:

\footnotetext{
Znacznej części życia społecznego doświadczamy dzięki procesom mentalnym, które nie są zamierzone i których raczej nie jesteśmy świadomi. Procesy te są automatycznie wyzwalane przez cechy najbliższego otoczenia społecznego, takie jak przynależność do grupy innych osób, jakość ich zachowania i właściwości sytuacji społecznych (np. normy, czyjaś względna przewaga). (Bargh, Williams 2006, 1)
}

W ten sposób bodźce i zdarzenia automatycznie uaktywniają wzorzec skojarzeń, który „szybko i automatycznie zapełnia się informacjami dotyczącymi wcześniej zaobserwowanych własności lub wcześniej doświadczonej reakcji afektywnej w sytuacjach, które przypominaja obecną" (Smith, DeCoster 2000, 110). Uaktywniają się własności stereotypowo kojarzone z takimi bodźcami, stając się w ten sposób bardziej dostępne świadomości, potencjalnie oddziałując na postrzeganie społeczne i zachowanie (Kunda, Spencer 2003). 


\section{Percepcja społeczna}

Przypuszczalnie najbardziej oczywistym bodźcem związanym z płcia, w który wyposaża nas nasze otoczenie społeczne, są sami ludzie, których niemalże każdorazowo, automatycznie kategoryzujemy jako mężczyzn i kobiety. Jak bardzo może to zniekształcać postrzeganie, pokazali w szczególnie uderzający sposób Thomas E. Nelson i jego współpracownicy, którzy zaprezentowali uczestnikom serię fotografii mężczyzn i kobiet, prosząc o ocenę ich wzrostu (Nelson, Biernat, Manis 1990). Chociaż przeciętnie mężczyźni oraz kobiety byli równego wzrostu (każdy mężczyzna został dopasowany do kobiety o takim samym wzroście), mężczyzn postrzegano jako znacznie wyższych. Tendencja do udzielania stronniczych odpowiedzi utrzymywała się, mimo że eksperymentatorzy zachęcali, by nie traktować płci jako wyznacznika wzrostu oraz obiecywali nagrodę pieniężną za bardziej trafne, niestronnicze oceny.

Nie dziwi zatem, że również w badaniach, w których ocenia się mniej obiektywne własności niż wzrost, mamy do czynienia z uprzedzeniami płciowymi. W eksperymentach typu „niemowlę X” naukowcy pokazują to samo niemowlę albo jako dziewczynkę, albo jako chłopca i obserwuja, jak wpływa to na zachowanie i percepcję uczestników badania. Zazwyczaj wykazuja one, że ludzie, kierując się stereotypami płciowymi, proponuja niemowlętom różne zabawki (Sidorowicz, Lunney 1980) i różnie postrzegają ich zachowania (Delk et al. 1986), w zależności od tego, czy powiedziano im, że niemowlę jest dziewczynką czy chłopcem. Można by argumentować, że rodzice, posiadający bardziej szczegółową wiedzę o swoich niemowlętach, nie będą tacy stronniczy. Niemniej Emily R. Mondschein i jej współpracownicy pokazali, że choć u jedenastomiesięcznych niemowląt nie ma różnicy między płciami w zdolności raczkowania czy skłonności do podejmowania ryzyka, to matki dziewczynek je zaniżały, a matki chłopców - zawyżały (Mondschein, Adolph, TamisLeMonda 2000). Podobnie Melissa W. Clearfield i Naree Nelson odkryły, że matki częściej rozmawiały i wchodziły w interakcję z niemowlętami i małymi dziećmi płci żeńskiej, mimo że nie było żadnych dostrzegalnych różnic płciowych w reakcjach dzieci na mowę matki czy bliskość fizyczną (2006).

Badania laboratoryjne „ludzi na papierze”2 w symulacjach procesu rekrutacyjnego przynosza kolejne dowody na to, że stereotypy płciowe wpływaja na percepcję społeczna w sposób wyraźnie niezamierzony i niezauważalny (najnowsze analizy tych badań można znaleźć w: Fuegen 2010; Heilman, Parks-Stamm 2010). Wskazano wiele przykładów, kiedy do tego dochodzi, włączając w to zaniżone oceny kwalifikacji kandydatek (Davison, Burke

\footnotetext{
${ }^{2}$ W originale „paper people”. Określenie to odnosi się do ludzi, których zachowania lub zdolności są oceniane przez uczestników eksperymentu na podstawie danych na ich temat przedstawionych „na papierze” w formie opisowej (ich CV, opisu zachowania w określonej sytuacji itd.) [przyp. tłum.].
} 
2000; Isaac, Lee, Carnes 2009), zmiany w hierarchii ważności kryteriów oceny, by faworyzować kandydata ze względu na jego płeć (Norton, Vandello, Darley 2004; Phelan, Moss-Racusin, Rudman 2008; Uhlmann, Cohen 2005), wyższe standardy, które muszą spełnić kandydatki, przedstawiane jako ogólne kryteria konieczne do spełnienia (Biernat, Kobrynowicz 1997) oraz szczególnie negatywna ocena matek (Correll, Benard, Paik 2007; Fuegen et al. 2004; Heilman, Okimoto 2008). Badania naukowe pokazały również, że zachodzi „efekt oporu” [backlash effects], polegający na tym, że kobiety, przeciwstawiające się swoim zachowaniem nakazom płciowym, penalizuje się społecznie i ekonomicznie. Prace laboratoryjne dowodzą, że efekt ten występuje w przypadku zatrudniania, negocjacji wysokości zarobków, awansów oraz oceny pracowniczej (zob. na przykład Bowles, Babcock, Lai 2007; Eagly, Makhijani, Klonsky 1992; Heilman et al., 2004; Okimoto, Brescoll 2010; Rudman 1998; Rudman, Glick 1999; Rudman, Glick 2001).

Uaktywnienie stereotypów płciowych może wpływać nie tylko na to jak postrzegamy innych, ale również siebie samych. Odkryto, że torowanie płci [priming gender] ${ }^{3}$ wpływa w sposób zgodny ze stereotypem na to, jak ludzie oceniają swoje umiejętności typowe dla którejś płci (jak zdolności matematyczne czy werbalne) (Chatard, Guimond, Selimbegovic 2007; Sinclair, Hardin, Lowery 2006). Torowanie płci zmniejsza także deklarowane przez kobiety zainteresowanie zajęciami i działaniami typowymi dla mężczyzn, jak inżynieria, funkcje przywódcze i matematyka (Davies et al. 2002; Davies, Spencer, Steele 2005; Steele, Ambady 2006). Co więcej, na to, jak ludzie postrzegają siebie samych, wpływa także ich przeświadczenie o tym, co myślą o nich inne osoby bliskie im towarzysko lub dla nich ważne. Zatem jeśli opinia B o A jest stereotypowa, a B jest w jakiś sposób ważna dla A, wtedy postrzeganie samej siebie przez A i być może nawet jej zachowanie zostaną „dostrojone” tak, by były zgodne ze sposobem, jaki postrzega ja B (Lewis, Smith, Hawkinson 2011; Sinclair et al. 2005; Sinclair, Lun 2006). Co więcej, Shelley J. Correll odkryła, że „przypisanie jakiegoś nowego zadania do płci” męskiej (to jest określenie, że lepiej wykonuja je mężczyźni), zmniejsza zarówno ocenę zdolności kobiet do wykonania tego zadania, jak i ich zainteresowanie podobnymi zadaniami (2004).

\footnotetext{
3 Torowanie to metoda, w której wystawienie na działanie określonego bodźca wpływa na sposób reagowania na kolejne bodźce, bez kontroli świadomości czy też nieintencjonalnie. Jest ona najskuteczniejsza, gdy oba bodźce są tego samego rodzaju (np. wizualne), ale zachodzi także, kiedy mamy do czynienia z modalnościami lub słowami powiązanymi ze sobą znaczeniowo. Zjawisko to jest często wykorzystywane w eksperymentach z psychologii poznawczej [przyp. tłum.].
} 


\section{Zagrożenie stereotypem}

Kategoria „zagrożenia stereotypem” (Steele 1997) określa szkodliwy wpływ, jaki na wykonanie danego zadania w kontekście społecznym ma uwypuklenie jakiegoś znaczącego, negatywnego stereotypu na temat określonej grupy społecznej (np. stereotypu, że kobiety są słabe z matematyki, słabe w testach matematycznych). Najczęściej badacze sprawdzają działanie tego efektu, porównując wykonanie zadania w warunkach, kiedy mamy i kiedy nie mamy z nim do czynienia. W tym pierwszym przypadku można przywołać go bezpośrednio lub polegać na tym, że uczestnicy badania sa świadomi tej kulturowo podzielanej wiedzy. Zatem kiedy badamy działanie stereotypu w przypadku zadań matematycznych, nie musimy wprost odwoływać się do stereotypu, że mężczyźni są lepsi w tej domenie. W warunkach, w których nie ma zagrożenia stereotypem, zadanie przedstawia się w sposób neutralny płciowo lub określa się stereotypy płciowe jako nieistotne (np. mówi się, że „w przypadku wykonywania tego testu nie znaleziono różnic ze względu na płeć”).

Badania sugeruja, że podstawowy mechanizm, poprzez który zagrożenie stereotypem zakłóca wykonanie zadania, polega na podejmowaniu prób stłumienia negatywnych myśli, negatywnych stereotypów i lęków na swój temat, co nakłada na procesy autoregulacji dodatkowe obciążenia (Schmader, Johns, Forbes 2008). Najnowsze metaanalizy pokazuja, że niekorzystny wpływ na wykonanie zadań nie jest czymś błahym. Gregory Walton i Steven Spencer wykazali, że wpływ zagrożenia stereotypem prowadzi do niedoszacowania kobiecych zdolności od 19 do 21 punktów w teście matematycznym SAT (w porównaniu z ogólnie 34 punktami różnicującymi płcie w skali całej populacji) (Walton, Spencer 2009). Kolejna z najnowszych metaanaliza dowodzi, że wpływ ten jest w przybliżeniu dwukrotnie większy u kobiet, które rozwiązują trudne testy matematyczne, a największy jest u kobiet, które podjęły wysiłek, by odnieść sukces w tej dziedzinie (Nguyen, Ryan 2008). Stopień umniejszania zdolności, na jaki wskazują te metaanalizy, sugeruje, że skutki zagrożenia stereotypem maja istotne praktyczne znaczenie w konkurencyjnym i wymagającym środowisku edukacyjnym oraz miejscu pracy. Co więcej, ostatnie badania świadczą o tym, że zagrożenie stereotypem może również upośledzać kobiece zdolności do uczenia się przedmiotów typowo wiązanych z płcią (jak chemia czy matematyka) (Good, Woodzicka, Wingfield 2010; Rydell, Rydell, Boucher 2010), wskazując, że wszechobecne zagrożenie stereotypem może szkodzić kobietom długotrwale, a nie tylko w momencie rozwiązywania testów. Dlatego nie należy lekceważyć rzeczywistego zagrożenia stereotypem, zwłaszcza biorąc pod uwagę argumenty, że różnice płci powstaja, kiedy narasta niewielka, subtelna, ale z czasem - znacząca przewaga po stronie mężczyzn, a rosną straty po stronie kobiet (Ridgeway, Correll,1998; Valian 1998). 
Istnieje również coraz więcej świadectw na to, że stereotypy płciowe moga spowodować, że kobiety będą miały pozorną przewagę, wykonując zadania typowe dla kobiet. Początkowe badania z wykorzystaniem testu „adekwatności empatii" (w których uczestnicy wyciagali wnioski na temat myśli i uczuć innych na podstawie nagrań wideo pokazujących ostatnie z nimi interakcje), nie wykazały różnicy między płciami (Graham, Ickes 1997; Ickes 2003), co sugeruje, że kobiety i mężczyźni posiadaja porównywalne zdolności do empatii poznawczej (choć używając innych testów. zaobserwowano niewielką przewagę kobiet) (Graham, Ickes 1997). Jednakże kiedy nieznacznie zmieniono formę testu i poproszono uczestników o oszacowanie trafności swoich sądów empatycznych, kobiety osiagnęły lepsze rezultaty (Zob. metaanalizę w: Ickes, Gesn, Graham 2000). William Ickes pokazuje, że ta niewielka zmiana przypomniała kobietom o stereotypie płciowym na temat kobiecej wrażliwości społecznej (2003). Podobnie inne badania wykazały słabsze wyniki mężczyzn niż kobiet, gdy testy zaprezentowano jako łatwiejsze dla kobiet, ale wyniki nie różniły się, gdy przedstawiono je bardziej neutralnie (Koenig, Eagly 2005; Leyens, Désert, Croizet 2000). Również Terrence G. Horgan i Jessi L. Smith pokazali, że obie płcie wypadły niekorzystnie, gdy test umiejętności interpersonalnych skonstruowano jako ważny dla zawodu tradycyjnie kojarzonego z druga płcią (przesłuchiwanie dla wojska versus praca społeczna) (2006).

Niektóre dowody przemawiaja za tym, że społeczno-kontekstowy wpływ na motywację ludzi, by wypaść dobrze w takich zadaniach może przyczynić się do powstania różnic płciowych w ich wykonaniu lub nawet stworzyć te różnice. Mężczyźni uzyskiwali w testach adekwatności empatii wyniki podobne do wyników kobiet, kiedy płacono im za poprawne odpowiedzi (Klein, Hodges 2001); wypadali też lepiej, kiedy dodano informację, że osiagnnięcie wysokiego wyniku oznacza sukcesy w miłości i w seksie (Thomas, Maio 2008), a słabiej, kiedy pojawiała się motywacyjna, oparta na emocjach potrzeba, by stosować się do społecznych norm męskości (Smith, Lewis 2009).

\section{Podsumowanie}

Przeanalizowane powyżej dane nieodparcie pokazuja, że stereotypy płciowe wpływaja na postrzeganie społeczne, postrzeganie siebie samych oraz zachowania typowe dla płci niczym samospełniająca się przepowiednia. Mimo to Baron-Cohen zaprotestowal niedawno przeciwko stawianiu takiego wniosku (2010). Przekonuje nas, że powinniśmy potraktować manipulacje społeczne, które redukują lub eliminują różnice między płciami, jako „formę interwencji” łagodzącej oddziaływanie naturalnych, „spontanicznych” różnic płciowych (2010, 904). Tym samym twierdzi on, że wnioskowanie, iż różnice zachowania u obu płci są rezultatem wpływu czynników społecznych i kontekstualnych jest błędne, analogicznie jak 
wnioskowanie, że skoro aspiryna może złagodzić ból głowy, to jej brak go powoduje. Taka interpretacja wymaga jednak podtrzymywania mało prawdopodobnej tezy, że krótkie i proste manipulacje wykorzystane w opisanych eksperymentach (takie jak informowanie uczestników badania, że nie znaleziono różnic ze względu na płeć w danym teście) mogą statystycznie wpłynąc na wykonanie testu, a mocno osadzone w naszej kulturze przekonania kulturowe oraz oczekiwania wobec płci są bez znaczenia (Fine 2010a).

\section{Jakie są skutki twierdzeń o głęboko zakorzenionych różnicach płciowych?}

Twierdzenia naukowe na temat głęboko zakorzenionych różnic płciowych są częścią kultury, która oddziałuje na nasze umysły. Idee te nie pozostaja zamknięte w obrębie literatury naukowej, ale (z różnym stopniem dokładności: Fine 2010a) rozprzestrzeniają się w społeczeństwie dzięki artykułom i książkom popularyzatorskim. „Fakty na temat mózgu” mogą szczególnie skutecznie wpływać na społeczeństwo dzięki „uwodzicielskiemu urokowi” neuronauk, ich widocznemu autorytetowi epistemicznemu (McCabe, Castel 2008; Weisberg et al. 2008) oraz sposobom, w jakie odkrycia neuronauk przedstawia się w popularnych mediach (Racine et al. 2010). Jakie skutki psychologiczne ma pojawienie się w sferze publicznej sugestii, że na przykład różnice płciowe w zdolności do empatii czy dokonaniach w nauce lub matematyce, filozofii lub technologiach informacyjnych przynajmniej częściowo można przypisać oddziaływaniu testosteronu płodowego na mózg? (Baron-Cohen 2009; Kimura 2005; Martin 2011; Tosh 2010). Rzecz jasna, by odpowiedzieć na to pytanie, należałoby uściślić sam sposób porównywania - mianowicie z czym te skutki porównujemy skoro nie istnieje coś takiego jak środowisko „neutralne”. Często bywa tak, że płeć biologiczna ma niewielki wpływ na różnorodność zachowań. Niektórzy uważają zatem, że z właściwym porównywaniem mamy do czynienia, kiedy artykuł rozważa tę samą domenę (np. umiejętności matematyczne lub zdolność do empatii), ale uwzględnia rolę, dajmy na to, czynników społeczno-ekonomicznych czy międzykulturowych.

Bardziej ostrożne porównywanie, dokonywane w badaniach eksperymentalnych, opiera się na danych wskazujących na płeć jako linię podziału społecznego oraz różnice między płciami, ale jednocześnie uwypukla przeciwstawienie między wpływami „środowiskowymi” i „biologicznymi”. Przyjmuje się ogólnie, że te ostatnie wskazuja, iż różnice między płciami są nieuchronne i stałe, co, jak wykazał Nick Haslam ze współpracownikami, stanowi ważny element esencjalistycznych przekonań na temat płci (Haslam, Rotschild, Ernst 2000).

Co zatem ustalono w takich badaniach? Po pierwsze, wstępne wyniki pokazują, że u podstaw szkodliwego wpływu zagrożenia stereotypem leży spontanicznie przyjmowane 
założenie, iż różnice płciowe są uwarunkowane „biologicznie”. Niedawno w dwóch badaniach dotyczących zagrożenia stereotypem porównano wpływ informacji o uwarunkowaniu różnic płciowych w zdolnościach matematycznych czynnikami genetycznymi z wpływem informacji o warunkowaniu czynnikami środowiskowymi. W obu ustalono, że mamy do czynienia z tym wpływem jedynie wtedy, gdy podajemy, że różnica płciowa w wykonaniu testów matematycznych wynika z czynników genetycznych (DarNimrod, Heine 2006; Thoman et al. 2008). Co więcej, odkryto, że przekonanie ludzi o zdolnościach intelektualnych w ogóle - niezależnie czy traktuja je jako coś trwale danego („,talent”) czy coś, co się nabywa („wyuczone”) - wpływa na wytrwałość i motywację, przy czym ci, którzy utrzymują, że zdolności te sa dane, słabiej radzą sobie z trudnościami. Przekonanie o wyższości mężczyzn w matematyce czy w nauce wzmacnia zarówno przekonanie, że takie zdolności są raczej dane (lub są talentem) niż wyuczone, jak i że tym „talentem” obdarowano przede wszystkim mężczyzn (Dweck, 2007). Co ciekawe, przeprowadzone na uczniach klasy siódmej badanie interwencyjne, w którym zakwestionowano pogląd o inteligencji jako czymś „z góry danym”, wyeliminowało różnice płciowe w wykonaniu standardowych testów matematycznych, jakie obserwowano w grupie kontrolnej bez żadnych interwencji (Good, Aronson, Inzlicht 2003).

Po drugie, zarówno poparcie dla „biologicznych” wyjaśnień różnic płciowych, jak i eksponowanie ujęć biologicznych wiąże się z większym przyzwoleniem dla stereotypów płciowych (Brescoll, LaFrance 2004; Martin, Parker 1995) i bardziej stereotypowym postrzeganiem samego siebie (Coleman, Hong 2008). To zaledwie jeden z przykładów ogólniejszej tendencji łączenia esencjalistycznych przekonań biologicznych z aprobowaniem szerokiego wachlarza stereotypów społecznych (Bastian, Haslam 2006). Należałoby zbadać wpływ stereotypów na postrzeganie siebie samych oraz zachowanie: trzeba by na przykład przyjrzeć się wpływowi na samoocenę zdolności do empatii oraz na rzeczywiste te zdolności u mężczyzn, których żony właśnie przeczytały książkę Mózg kobiety (Brizendine 2007), na obwolucie której czytamy, że „mężczyzna wydaje się nie dostrzegać emocji, chyba że ktoś płacze lub grozi uszkodzeniem ciała". Niemniej dane, którym przyglądaliśmy się wcześniej przekonują, że takie oddziaływanie może pojawić się za pośrednictwem wpływu zarówno na indywidualne postrzeganie samego siebie, jak i na sposób, w jaki dana osoba odbiera przekonania swoich bliskich na swój temat.

Po trzecie, istnieją świadectwa wskazujące, że silniejsze podkreślanie wpływu genów na zachowanie wiąże się $z$ większą tolerancją dla zachowania społecznego status quo. Johannes Keller odkrył, że aprobata dla determinizmu genetycznego łączy się ze współczesnym seksizmem (to jest zaprzeczaniem, że seksizm jeszcze istnieje, wrogim nastawieniem do postulatów feministycznych i niezadowoleniem $z$ takich strategii politycznych jak działania afirmacyjne) (Keller 2005). Podobnie Michaël Dambrun i jego współpracownicy 
zaobserwowali, że przekonanie o zasadności hierarchii społecznej malało u studentów, którzy podejmowali studia psychologiczne (gdzie skupiano się na społecznym, sytuacyjnym i środowiskowym wpływie na zachowanie), ale nie u studentów biologii, mimo podobnych postaw na początku studiów (Dambrun et al. 2009). Ta zmiana wzięła się z rosnącej wiary w determinizm biologiczny.

Badania pokazują, że przeświadczenie o tym, że różnice między grupami społecznymi są u swych podstaw biologiczne, naturalizuje nierówność i spełnia funkcję uprawomocniania systemu, zarówno ogólnie (Yzerbyt, Rocher, Schadron 1997), jak i w odniesieniu do płci (Bem 1993). Potwierdzając istnienie takiego systemu, który leży u podstaw biologicznych, esencjalistycznch ujęć płci, Thomas Morton i jego współpracownicy wskazali na istnienie powiązań pomiędzy przekonaniami esencjalistycznymi a seksizmem wyłącznie u mężczyzn i tylko wtedy, kiedy kobiety przedstawiano jako odrabiające straty wobec mężczyzn. Odwrotnie, pokazali oni także, że twierdzenia naukowe na temat płci wpływaja na poparcie dla hierarchii, która legitymizuje takie przekonania i nastawienie. Odkryli oni, że kiedy przedstawi się twierdzenia naukowe o głęboko zakorzenionych różnicach między mężczyznami a kobietami (w porównaniu z badanymi, którym powiedziano, że takie idee sa przedmiotem toczącej się dyskusji naukowej), ludzie wykazują się większą pewnościa co do tego, że społeczeństwo traktuje kobiety sprawiedliwie i mniejszą pewnością co do tego, że status quo może się zmienić. Co więcej, mężczyźni, którzy uczestniczyli w tych badaniach, silniej opowiadali się za dyskryminacja płciową w miejscu pracy po lekturze tego typu materiałów (Morton, Haslam, Hornsey 2009).

\section{Potrzeba dalszych badań}

Powyżej przedstawione badania pokazuja, że teorie naukowe na temat różnic płciowych w poznaniu i zachowaniu wpływają na badane zjawiska mentalne (Hacking 1995; Choudhury, Nagel, Slaby 2009) i niezależnie od swojej prawdziwości oddziałuja na ludzkie życie i społeczeństwo jak samospełniająca się przepowiednia (Schwartz 1997). Haslam przekonuje, że myślenie esencjalistyczne na temat grup społecznych przynosi szkodliwe skutki zarówno za pośrednictwem postrzegania różnic między grupami społecznymi oraz odbioru prawomocności stereotypów społecznych, jak i za sprawą przekonań na temat trwałości i naturalności różnic między tymi grupami (2011). Podsumowuje on: „esencjalizm pogłębia podziały społeczne, sprawiając, że różnice wyglądają na większe, nie do pokonania, nieuniknione, niezmienne i ustanowione przez nature". W przyszłości dobrze byłoby zbadać dokładniej oddziaływanie przekonań czy twierdzeń o głęboko zakorzenionych różnicach 
płciowych na percepcję, postrzeganie samych siebie i zachowanie oraz kryjące się za nimi mechanizmy.

Na przykład, czy takie przekonania lub stwierdzenia zwiększają uprzedzenia płciowe w przypadku oceniania innych i/lub powoduja efekt oporu wobec kobiet, które naruszaja nakazy płciowe? Jeśli tak, budzi to słuszne obawy, zwłaszcza jeśli pomyślimy o popularności kursów dokształcających o różnorodności płciowej dla korporacji, które opierają się na pojęciu głęboko zakorzenionych różnic płciowych (Gurian, Annis 2008). Czy takie twierdzenia wpływaja na bardziej stereotypowe postrzeganie i socjalizowanie dzieci przez rodziców i nauczycieli? Jeśli tak, raz jeszcze byłoby to bardzo niepokojące, jeśli weźmiemy pod uwagę wzrost roli strategii edukacyjnych rekomendowanych dla szkól, rzekomo opartych na „badaniach mózgu” (Gurian, Stevens 2004; Sax 2006). Czy takie twierdzenia zmniejszaja poparcie dla programów, których celem jest zwiększenie uczestnictwa kobiet w tradycyjnie męskich dziedzinach i/lub pozytywne nastawienie do tych programów? Czy wpływają one na oczekiwania heteroseksualnych małżonek co do roli ich partnerów w wykonywaniu prac domowych (Gaunt 2006)? Czy wpływaja na to, jak postrzegamy swoje zdolności i zainteresowania domenami typowymi dla określonej płci? Przedstawione powyżej wyniki badań wskazują że istnieje wiele możliwych mechanizmów, które moga stać za opisywanym zjawiskiem, włączając rosnące długotrwałe poparcie dla stereotypów płciowych, krótkotrwałe uaktywnienie stereotypów płciowych, zmniejszoną motywację do kontrolowania uprzedzeń, rosnące samozadowolenie dotyczące status quo i zmieniający się sposób postrzegania opisowych i/lub preskryptywych norm społecznych.

Kończąc, stwierdzam, że dostępne badania nawet w obecnej postaci wystarczają, by bić na alarm etyczny. Esencjalistyczne teorie biologiczne na temat różnic płciowych maja długą i przykrą historię, w której twierdzenia naukowe na temat różnic między kobietami i mężczyznami, później odrzucone, służyły wyjaśnieniu, uprawomocnieniu oraz wzmocnieniu status quo (Fausto-Sterling 1992; Russett 1989; Shields 1975). Jak w przypadku wielu przypuszczeń naukowych, hipoteza na temat organizacji mózgu oraz twierdzenia o różnicach płciowych w mózgu i ich związku z zachowaniem są przedmiotem dyskusji i można je obalić. Ponadto, o czym była mowa we wprowadzeniu, przedstawiono słuszne zastrzeżenia co do zasadności wniosków, które wyprowadzono z dostępnych wyników badań (Fine 2010b; Grossi, Fine 2012; Jordan-Young 2010). Kiedy weźmiemy pod uwagę omawiany w niniejszym artykule faktyczny wpływ efektów badań na nasze umysły i społeczeństwo, rodzą się ważne pytania o odpowiedzialność etyczną prowadzących je naukowców.

\section{Podziękowania:}

Autorka dziękuje Nickowi Haslamowi za jego cenne komentarze do wcześniejszej wersji tego artykułu. 


\section{Wykaz literatury}

Bargh, J.A. i E. L. Williams. 2006. „The automaticity of social life”. Current Directions in Psychological Science 15 (1): 1-4.

Baron-Cohen, S. 2003. The essential difference: Men, women and the extreme male brain. London: Allen Lane.

Baron-Cohen, S. 2009. „Autism test »could hit maths skills«”. BBC News: http:// news.bbc.co.uk/2/hi/health/7736196.stm. Dostęp 2 lutego 2009.

Baron-Cohen, S. 2010. „Delusions of gender—»neurosexism«, biology and politics”. The Psychologist. 23(11): 904-905.

Baron-Cohen, S., R. C. Knickmeyer i M.K. Belmonte. 2005. „Sex differences in the brain: Implications for explaining autism”. Science 310: 819-823.

Bastian, B. i N. Haslam. 2006. „Psychological essentialism and stereotype endorsement”. Journal of Experimental Social Psychology 42(2): 228-235.

Bem, S. L. 1983. „Gender schema theory and its implications for child development: Raising gender-aschematic children in a gender-schematic society". SIGNS: Journal of Women in Culture \& Society 8(4): 598-616.

Bem, S. L. 1993. The lenses of gender: Transforming the debate on sexual inequality. New Haven: Yale University Press.

Biernat, M. i D. Kobrynowicz. 1997. „Gender- and race-based standards of competence: Lower minimum standards but higher ability standards for devalued groups". Journal of Personality \& Social Psychology 72 (3): 544-557.

Bowles, R.P., L. Babcock i L. Lai. 2007. „Social incentives for gender differences in the propensity to initiate negotiations: Sometimes it does hurt to ask". Organizational Behavior and Human Decision Processes 103(1): 84-103.

Brescoll, V. i M. LaFrance. 2004. „The correlates and consequences of newspaper reports of research on sex differences". Psychological Science 15(8): 515-520.

Brizendine, L. 2007. The female brain. London: Bantam Press. [wyd. pol. 2006. Mózg kobiety. Tłum. P.J. Szwajcer, A. E. Eichler, Gdańsk: VM Media Group].

Chatard, A., S. Guimond i L. Selimbegovic. 2007. „»How good are you in math?« The effect of gender stereotypes on students' recollection of their school marks. Journal of Experimental Social Psychology 43(6): 1017-1024.

Choudhury, S., S.K. Nagel i J. Slaby. 2009. „Critical neuroscience: Linking neuroscience and society through critical practice". BioSocieties 4: 61-77.

Clearfield, M.W. i N.M. Nelson. 2006. „Sex differences in mothers' speech and play behavior with 6-, 9-, and 14- month-old infants". Sex Roles 54(1/2): 127-137.

Coleman, J.M. i Y.-Y. Hong. 2008. „Beyond nature and nurture: The influence of lay gender theories on self stereotyping". Self and Identity 7(1): 34-53.

Correll, S.J. 2004. „Constraints into preferences: Gender, status, and emerging career aspirations". American Sociological Review 69(1): 93-113.

Correll, S.J., S. Benard i I. Paik. 2007. „Getting a job: Is there a motherhood penalty?” American Journal of Sociology 112(5): 1297-1338.

Dambrun, M., R. Kamiejski, N. Haddadi i S. Duarte. 2009. „,Why does social dominance orientation decrease with university exposure to the social sciences? The impact of institutional socialization and the mediating role of "geneticism «". European Journal of Social Psychology 39(1): 88-100.

Dar-Nimrod, I. i S.J. Heine. 2006. „Exposure to scientific theories affects women's math performance". Science 314: 435. 
Davies, P.G., S.J. Spencer i C.M. Steele. 2005. „Clearing the air: Identity safety moderates the effects of stereotype threat on women's leadership aspirations". Journal of Personality \& Social Psychology 88(2): 276-287.

Davies, P.G., S.J. Spencer, D.M. Quinn i R. Gerhardstein. 2002. „Consuming images: How television commercials that elicit stereotype threat can restrain women academically and professionally". Personality \& Social Psychology Bulletin 28(12): 1615-1628.

Davison, H.K. i M.J. Burke. 2000. „Sex discrimination in simulated employment contexts: A meta-analytic investigation". Journal of Vocational Behavior 56(2): 225-248.

Delk, J.L., R.B. Madden, M. Livingston i T.T. Ryan. 1986. „Adult perceptions of the infant as a function of gender labeling and observer gender". Sex Roles 15(9/10): 527-534.

Dweck, C.S. 2007. „Is math a gift? Beliefs that put females at risk”. W Why aren't more women in science? Top researchers debate the evidence, red. S.J. Ceci and W.M. Williams. Washington D.C.: American Psychological Association.

Eagly, A.H., M.G. Makhijani i B.G. Klonsky. 1992. „Gender and the evaluation of leaders: A metaanalysis". Psychological Bulletin 111(1): 3-22.

Fausto-Sterling, A. 1992. Myths of gender: Biological theories about women and men. New York: Basic Books.

Fine, C. 2010a. „Seductive arguments”. The Psychologist 23 (12): 948-949.

Fine, C. 2010b. Delusions of gender: How our minds, society, and neurosexism create difference. New York: Norton.

Fine, C. 2010c. „From scanner to sound bite: Issues in interpreting and reporting sex differences in the brain". Current Directions in Psychological Science 19(5): 280-283.

Fuegen, K. 2010. „The effects of gender stereotypes on judgments and decisions in organizations". W Social psychology of gender (Advances in group processes, volume 24), red. S.J. Correll. Emerald Group Publishing.

Fuegen, K., M. Biernat, E. Haines i K. Deaux. 2004. „Mothers and fathers in the workplace: How gender and parental status influence judgments of job-related competence". Journal of Social Issues 60(4): 737-754.

Gaunt, R. 2006. „Biological essentialism, gender ideologies, and role attitudes: What determines parents' involvement in child care". Sex Roles 55(7/8): 523-533.

Good, C., J. Aronson i M. Inzlicht. 2003. „Improving adolescents’ standardized test peformance: An intervention to reduce the effects of stereotype threat". Journal of Applied Developmental Psychology 24(6): 645-662.

Good, J.J., J.A. Woodzicka i L.C. Wingfield. 2010. „The effects of gender stereotypic and counter-stereotypic textbook images on science performance". Journal of Social Psychology 150(2): 132-147.

Graham, T. i W. Ickes. 1997. „When women's intuition isn't greater than men's”. W Empathic accuracy, red. W. Ickes. New York: Guilford.

Grossi, G i C. Fine 2012. „The role of fetal testosterone in the development of »the essential difference« between the sexes: Some essential issues. In: Neurofeminism: Issues at the intersection of feminist theory and cognitive neuroscience, pod red. R. Bluhm, A.J. Jacobson i H.L. Maibom. 73-105. Basingstoke: Palgrave Macmillan.

Grossi, G. 2008. „Science or belief? Bias in sex differences research”. W Under-representation of women in science and technology, red. S. Badaloni, C.A. Drace, O. Gia, C. Levorato i F. Vidotto, 93-106. Padova: Cleup.

Gur, R.C. i R.E. Gur. 2007. „Neural substrates for sex differences in cognition”. W Why aren't more women in science? Top researchers debate the evidence, red. S.J. Ceci, and W.M. Williams, 189-198. Washington D.C.: American Psychological Association. 
Gurian, M i K. Stevens. 2004. „With boys and girls in mind”. Educational Leadership 62(3): 2126.

Gurian, M. i B. Annis. 2008. Leadership and the sexes: Using gender science to create success in business. San Francisco: Jossey-Bass.

Hacking, I. 1995. „The looping effects of human kinds”. W Causal cognition: a multidisciplinary debate, red. D. Sperber, D. Premack i A.J. Premack. Oxford: Oxford University Press.

Halpern, D.F., C.P. Benbow, D.C. Geary, R.C. Gur, J.S. Hyde i M.A. Gernsbacher. 2007. „The science of sex differences in science and mathematics". Psychological Science in the Public Interest 8(1): 1-51.

Haslam, N. 2011. „Genetic essentialism, neuro-essentialism, and stigma: Comment on DarNimrod \& Heine”. Psychological Bulletin 137 (5): 819-824.

Haslam, N., L. Rothschild i D. Ernst. 2000. „Essentialist beliefs about social categories”. British Journal of Social Psychology 39(1): 113-127.

Heilman, M.E. i E.J. Parks-Stamm. 2010. „Gender stereotypes in the workplace: obstacles to women's career progress". W Social psychology of gender (Advances in group processes, volume 24), red. S.J. Correll. Emerald Group Publishing.

Heilman, M.E. i T.G. Okimoto. 2008. „Motherhood: A potential source of bias in employment decisions". Journal of Applied Psychology 93(1): 189-198.

Heilman, M.E., A.S. Wallen, D. Fuchs i M.M. Tamkins. 2004. „Penalties for success: Reactions to women who succeed at male gender-typed tasks". Journal of Applied Psychology 89(3): 416-427.

Herschel, A J. 1965. Who is man?. Stanford: Stanford University Press.

Hines, M. 2010. „Sex-related variation in human behaviour and the brain”. Trends in Cognitive Sciences 14(10): 448- 456.

Horgan, T.G. i J.L. Smith. 2006. „Interpersonal reasons for interpersonal perceptions: Gender-incongruent purpose goals and nonverbal judgment accuracy". Journal of Nonverbal Behavior 30(3): 127-140.

Ickes, W. 2003. Everyday mind reading: Understanding what other people think and feel. Amherst: Prometheus Books.

Ickes, W., P.R. Gesn i T. Graham. 2000. „Gender differences in empathic accuracy: Differential ability or differential motivation?”. Personal Relationships 7(1): 95-109.

Isaac, C., B. Lee i M. Carnes. 2009. „Interventions that affect gender bias in hiring: A systematic review". Academic Medicine 84(10): 1440-1446.

Jordan-Young, R.M. 2010. Brain storm: The flaws in the science of sex differences. Cambridge: Harvard University Press.

Kaiser, A., S. Haller, S. Schmitz i C. Nitsch. 2009. „On sex/gender related similarities and differences in fMRI language research". Brain Research Reviews 61(2): 49-59.

Keller, J. 2005. „In genes we trust: The biological component of psychological essentialism and its relationship to mechanisms of motivated social cognition". Journal of Personality \& Social Psychology 88(4): 686-702.

Kimura, D. 2005. „Hysteria trumps academic freedom”. Vancouver Sun, s. A13.

Kitayama, S. i D. Cohen. 2007. „Preface”. W Handbook of cultural psychology, red. S. Kitayama I D. Cohen. New York: Guilford.

Klein, K.J.K. i S.D. Hodges. 2001. „Gender differences, motivation, and empathic accuracy: When it pays to understand". Personality and Social Psychology Bulletin 27(6): 720-730.

Koenig, A.M. i A.H. Eagly. 2005. „Stereotype threat in men on a test of social sensitivity”. Sex Roles 52(7/8): 489-496. 
Kunda, Z. i S.J. Spencer. 2003. „When do stereotypes come to mind and when do they color judgment? A goal-based theoretical framework for stereotype activation and application". Psychological Bulletin 129 (4): 522-544.

Lewis, K.L., J.L. Smith i K.E. Hawkinson. 2011. „Tuning out in order to fit in: The effects of gender role expectations and affiliation motives on men's interpersonal sensitivity". W Managing Interpersonal Sensitivity: Knowing when - and when not - to understand others, red. J. L. Smith, W. Ickes i S.D. Hodges. Hauppauge: Nova Science Publishers.

Leyens, J.-P., M. Désert i J.-C. Croizet. 2000. „Stereotype threat: are lower status and history of stigmatization preconditions of stereotype threat?". Personality \& Social Psychology Bulletin 26(10): 1189-1199.

Martin, A. 2010. „Beyond understanding”. From New York Times online: http://opinionator.blogs.nytimes.com/2010/11/21/beyond-understanding/. Dostęp 27 maja 2011.

Martin, C.L. i S. Parker. 1995. „Folk theories about sex and race differences”. Personality \& Social Psychology Bulletin 21(1): 45-57.

McCabe, D.P. i A.D. Castel. 2008. „Seeing is believing: The effect of brain images on judgments of scientific reasoning". Cognition 107(1): 343-352.

Miller, C.F., H.M. Trautner i D.N. Ruble. 2006. „The role of gender stereotypes in children's preferences and behaviour". W Child psychology: A bandbook of contemporary issues, red. L Balter i CS Tamis-LeMonda. New York: Psychology Press.

Mondschein, E.R., K.E. Adolph i C.S. Tamis- LeMonda. 2000. „Gender bias in mothers’ expectations about infant crawling". Journal of Experimental Child Psychology 77: 304-316.

Morton, T.A., S.A. Haslam i M.J. Hornsey. 2009. „Theorizing gender in the face of social change: Is there anything essential about essentialism?”. Journal of Personality \& Social Psychology 96(3): 653-664.

Nelson, T.E., M.R. Biernat i M. Manis. 1990. „Everyday base rates (sex stereotypes): Potent and resilient". Journal of Personality \& Social Psychology 59(4): 664-675.

Nguyen, H.D. i A.M. Ryan. 2008. „Does stereotype threat affect test performance of minorities and women? A meta-analysis of experimental evidence". Journal of Applied Psychology 93(6): 1314-1334.

Norton, M.I., J.A. Vandello i J.M. Darley. 2004. „Casuistry and social category bias”. Journal of Personality \& Social Psychology 87(6): 817-831.

Nosek, B.A., F.L. Smyth, N. Sriram, N.M. Lindner, T. Devos, A. Ayala, Y. Bar-Anan, et al. 2009. „National differences in gender-science stereotypes predict national sex differences in science and math achievement". PNAS 106(26): 10593-10597.

Okimoto, T.G. i V.L. Brescoll. 2010. „The price of power: Power seeking and backlash against female politicians”. Personality \& Social Psychology Bulletin 36 (7): 923-936.

Phelan, J.E., C.A. Moss-Racusin i L.A. Rudman. 2008. „Competent yet out in the cold: Shifting criteria for hiring reflect backlash toward agentic women”. Psychology of Women Quarterly 32(4): 406-413.

Prentice, D.A. i E. Carranza. 2002. „What women and men should be, shouldn't be, are allowed to be, and don't have to be: The contents of prescriptive gender stereotypes". Psychology of Women Quarterly 26(4): 269-281.

Racine, E., S. Waldman, J. Rosenberg i J. Illes. 2010. „Contemporary neuroscience in the media". Social Science \& Medicine 71(4): 725-733.

Ridgeway, C.L. i S.J. Correll. 2004. „Unpacking the gender system: A theoretical perspective on gender beliefs and social relations". Gender \& Society 18(4): 510-531. 
Rudman, L.A. 1998. „Self-promotion as a risk factor for women: The costs and benefits of counterstereotypical impression management". Journal of Personality \& Social Psychology 74(3): 629-645.

Rudman, L.A. i P. Glick. 1999. „Feminized management and backlash toward agentic women: the hidden costs to women of a kinder, gentler image of middle managers". Journal of Personality \& Social Psychology 77 (5): 1004-1010.

Rudman, L.A. i P. Glick. 2001. „Prescriptive gender stereotypes and backlash toward agentic women". Journal of Social Issues 57(4): 743-762.

Russett, C.E. 1989. Sexual science: the Victorian construction of womanhood. Cambridge: Harvard University Press.

Rydell, R.J., M.T. Rydell i K.L. Boucher. 2010. „The effect of negative performance stereotypes on learning". Journal of Personality \& Social Psychology. 99(6): 883-896.

Sax, L. 2006. Why gender matters: What parents and teachers need to know about the emerging science of sex differences. New York: Broadway Books.

Schmader, T., M. Johns i C. Forbes. 2008. „An integrated process model of stereotype threat effects on performance". Psychological Review 115(2): 336- 356.

Schwartz, B. 1997. „Psychology, idea technology, and ideology”. Psychological Science 8(1): 2127.

Shields, S. 1975. „Functionalism, darwinism, and the psychology of women”. American Psychologist 30: 739-754.

Sidorowicz, L.S. i G.S. Lunney. 1980. „Baby X revisited”. Sex Roles 6(1): 67-73.

Sinclair, S. i J. Lun. 2006. „Significant other representations activate stereotypic self-views among women". Self and Identity 5(2): 196-207.

Sinclair, S., C.D. Hardin i B.S. Lowery. 2006. „Selfstereotyping in the context of multiple social identities". Journal of Personality and Social Psychology 90(4): 529-542.

Sinclair, S., J. Huntsinger, J. Skorinko i C.D. Hardin. 2005. „Social tuning of the self: Consequences for the selfevaluations of stereotype targets. Journal of Personality \& Social Psychology 89(2): 160-175.

Smith, E.R. i J. DeCoster. 2000. „Dual-process models in social and cognitive psychology: Conceptual integration and links to underlying memory systems". Personality \& Social Psychology Review 4(2): 108-131.

Smith, J.L. i K.L. Lewis. 2009. „Men’s interpersonal (mis)perception: fitting in with gender norms following social rejection. Sex Roles 61(3/4): 252-264.

Steele, C.M. 1997. „A threat in the air: How stereotypes shape intellectual identity and Performance". American Psychologist 52(6): 613-629.

Steele, J.R. i N. Ambady. 2006. ,»Math is hard!« The effect of gender priming on women's attitudes". Journal of Experimental Social Psychology 42(4): 428-436.

Thoman, D.B., P.H. White, N. Yamawaki i H. Koishi. 2008. „Variations of gender-math stereotype content affect women's vulnerability to stereotype threat'. Sex Roles 58(9/10): 702-712.

Thomas, G. i G.R. Maio. 2008. „Man, I feel like a woman: When and how gender-role motivation helps mind-reading”. Journal of Personality \& Social Psychology 95(5): 11651179 .

Tosh, J. 2010. „The »extreme male brain« theory of why men are better suited to IT: CyComp 2010 conference report". Psychology of Women Section Review 12(2): 29-32.

Uhlmann, E.L. i G.L. Cohen. 2005. „Constructed criteria: Redefining merit to justify discrimination". Psychological Science 16(6): 474-480.

Valian, V. 1998. Why so slow? The advancement of women. Cambridge: MIT. 
Walton, G.M. i S.J. Spencer. 2009. „Latent ability: Grades and test scores systematically underestimate the intellectual ability of negatively stereotyped students". Psychological Science 20(9): 1132-1139.

Weisberg, D.S., F.C. Keil, J. Goodstein, E. Rawson i J. R. Gray. 2008. „The seductive allure of neuroscience explanations". Journal of Cognitive Neuroscience 20(3):470-477.

Yzerbyt, V., S. Rocher i G. Schadron. 1997. „Stereotypes as explanations: A subjective essentialist view of group perception". W The social psychology of stereotyping and group life, red. R. Spears, P.J. Oakes, N. Ellemers i S.A. Haslam, 20-50. Malden: Blackwell Publishing. 
Cordelia Fine - profesor historii i filozofii nauki na Uniwersytecie Melbourne, w Australii. Naukowo zajmuje się poznaniem społecznym, neuroseksizmem oraz popularnymi mitami dotyczącymi różnicy płci. Jest autorką trzech, wielokrotnie nagradzanych, książek popularnonaukowych: A Mind of Its Own (W. W. Norton 2006), Delusions of Gender (W. W. Norton 2010) oraz Testosterone Rex (W. W. Norton 2017).

\section{DANE ADRESOWE:}

Centre for Agency, Values \& Ethics

Macquarie University, Sydney, Australia

Melbourne Business School

University of Melbourne, 200 Leicester St., Carlton, Victoria 3053, Australia

EMAIL: c.fine@mbs.edu

CYTOWANIE: Fine, Cordelia. „Wyjaśniamy czy utrzymujemy status quo? Teorie o „głęboko zakorzenionych” różnicach płciowych jako samospełniająca się przepowiednia”. Praktyka Teoretyczna 2(28): 171-189.

DOI: $10.14746 /$ prt.2018.2.9

\section{AUTHOR: Cordelia Fine}

TITLE: Explaining, or Sustaining, the Status Quo? The Potentially Self-Fulfilling Effects of 'Hardwired' Accounts of Sex Differences.

ABSTRACT: In this article I flesh out support for observations that scientific accounts of social groups can influence the very groups and mental phenomena under investigation. The controversial hypothesis that there are hardwired differences between the brains of males and females that contribute to sex differences in gender-typed behaviour is common in both the scientific and popular media. Here I present evidence that such claims, quite independently of their scientific validity, have scope to sustain the very sex differences they seek to explain. I argue that, while further research is required, such claims can have selffulfilling effects via their influence on social perception, behaviour and attitudes. The real effects of the products of scientists' research on our minds and society, together with the fact that all scientific hypotheses are subject to dispute and disconfirmation, point to a need for scientists to consider the ethical implications of their work.

KEYWORDS: essentialism, neuroethics, gender, stereotypes. 